\title{
CORNEAL OPACITY AFTER PARTIAL LAMELLAR KERATECTOMY*
}

\author{
BY \\ ALY MORTADA \\ Department of Ophthalmology, Faculty of Medicine, Cairo University, Egypt
}

CASTROviEJo (1955) stated that opacities of the cornea, provided that they did not involve the whole thickness might be removed by clean dissection of the affected external layers. If infection, formation of granulation tissue, or revascularization is prevented during the post-operative period, the epithelium grows over the dissected area, the cornea remains transparent or fairly transparent, and visual improvement results. The depth of dissection depends upon that of the opacity, usually from one-third to a half of the corneal thickness has to be removed before a clear corneal stroma is reached. In some of these cases as much as two-thirds of the corneal thickness requires excision in order to remove all or most of the opacified cornea. If cloudiness develops over the pupillary area and the visual improvement is insufficient for the patient's needs, a partial lamellar or partial penetrating keratoplasty may still be performed.

\section{Present Investigations}

Material.-Ten cases of corneal superficial avascular central nebulae were operated upon by partial lamellar keratectomy to study the post-operative visual and cosmetic results. All these corneal nebulae were due to superficial corneal ulcers in cases of acute muco-purulent ophthalmitis. Slit-lamp examination showed that, apart from the central corneal opacity occupying one-third to two-thirds of anterior corneal lamellae, the anterior segment of the eye was normal. Conjunctival smears were negative for micro-organisms and the fundi were normal. Refraction, corrected visual acuity, and ocular tension were recorded before the operation and monthly thereafter. The general condition of each patient was good. There were no septic foci in the body. The blood Wassermann reaction was negative, and the urine was negative for albumen and sugar.

The patients received general vitamin A, B-complex, and C, and local vitamin $\mathrm{A}$ and terramycin eye ointment 7 days before and one month after the operation

* Received for publication April 30, 1962. 
Operative Procedure. - As the patients' ages ranged from 20 to 40 years, the operation was done under local anaesthesia. Surface Pantocaine, retrobulbar Novocaine, and O'Brien's akinesia were used. Superior rectus and lower lid sutures were inserted to open the palpebral aperture. A Franceschetti $5-\mathrm{mm}$. corneal trephine was adjusted to cut $0.3 \mathrm{~mm}$. of corneal thickness, and applied to the central area of the cornea (Fig. 1).

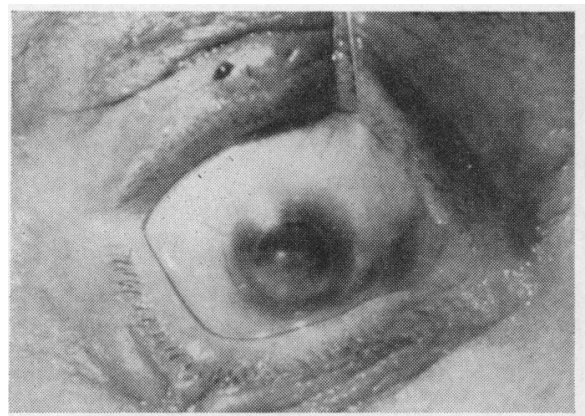

FIG. 1.-Superficial central corneal opacity and corneal mark of 5-mm. trephine. Ocular tension $24 \mathrm{~mm}$. $\mathrm{Hg}$ (Schiötz).

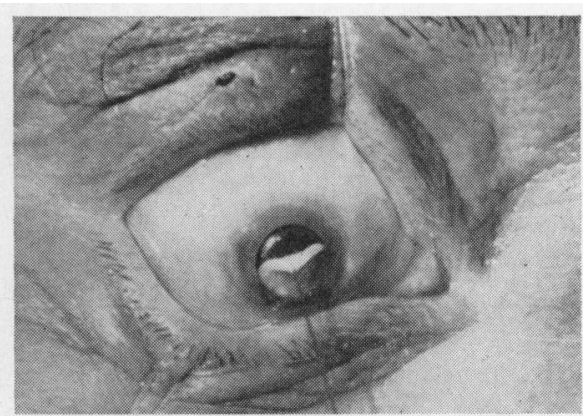

Fig. 2.-Partial lamellar keratectomy, showing traction suture and corneal lamellar separation along the plane of cleavage.

The depth required to reach a lamellar cleavage plane was noted when it was possible to evert the edge of the corneal disc with a corneal forceps. A traction suture was applied to the upper edge of the corneal disc and the corneal lamellae were split with a Barraquer's pyriform knife or a Desmarres's scarifier, thus removing the affected lamellae (Fig. 2).

If any vessels were cut Beta-rays 500r were applied at the end of the operation and twice more at weekly intervals to prevent vascularization of the deep central lamellae. A bandage was applied to the operated eye for 10 days, the dressing being changed every other day.

Post-operative Observations. For 4 days after the operation the keratectomy bed remained clear and depressed (Fig. 3, opposite).

Then the keratectomy bed became covered by epithelium and still remaining clear it became slightly ectatic and level with the surrounding corneal surface. In many cases, however, by the second week a disappointing progressive diffuse opacity appeared, and did not respond to local terramycin, vitamin A, pilocarpine, or cortisone ointments, to general Diamox, penicillin, or cortisone. The post-operative opacity was larger and denser than the original nebula for which the operation was done (Fig. 4, opposite). The ocular tension remained at the same level as before the operation.

The clinical details of the ten cases are shown in the Table (opposite).

Follow-up.-Observation of these cases for 2 years showed that in those in which the ocular tension was low (i.e. 8 to $12 \mathrm{~mm}$. $\mathrm{Hg}$ ) as in Cases 8,9 , and 10 , no post-keratectomy corneal opacity developed and the thin corneal 


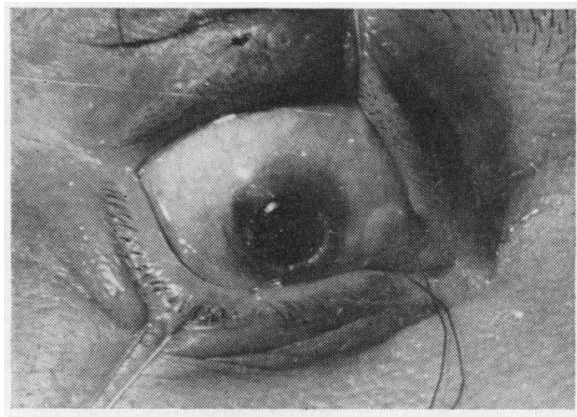

FIG. 3.-Clear keratectomy bed immediately after removal of $0.3 \mathrm{~mm}$. superficial corneal lamellae.

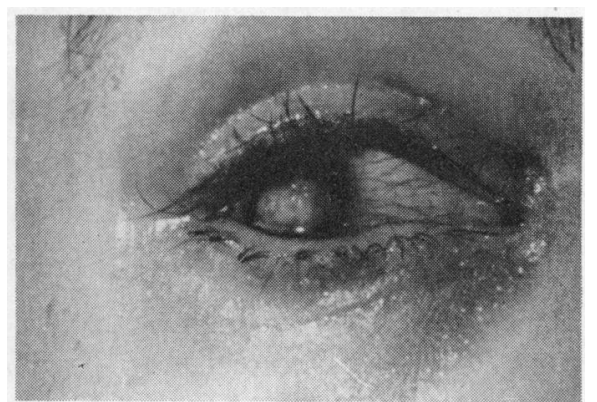

FIG. 4.-Large dense opacity affecting the thin corneal lamellae one month after keratectomy. Ocular tension $24 \mathrm{~mm}$. $\mathrm{Hg}$ (Schiötz).

TABLE

CLINICAL DETAILS OF TEN CASES

\begin{tabular}{|c|c|c|c|c|c|c|c|c|c|}
\hline \multirow{2}{*}{$\begin{array}{l}\text { Ocular } \\
\text { Tension }\end{array}$} & \multirow{2}{*}{$\begin{array}{l}\text { Case } \\
\text { No. }\end{array}$} & \multirow{2}{*}{$\begin{array}{l}\text { Age } \\
\text { (yrs) }\end{array}$} & \multirow{2}{*}{ Sex } & \multicolumn{2}{|c|}{ Before Operation } & \multirow{2}{*}{$\begin{array}{l}\text { Ocular } \\
\text { Tension } \\
\text { before } \\
\text { and after } \\
\text { Operation } \\
\text { (mm. Hg) }\end{array}$} & \multicolumn{3}{|c|}{40 days after Operation } \\
\hline & & & & $\begin{array}{l}\text { Refrac- } \\
\text { tion } \\
\text { (D sph.) }\end{array}$ & $\begin{array}{c}\text { Corrected } \\
\text { Visual } \\
\text { Acuity }\end{array}$ & & Cornea & $\begin{array}{c}\text { Refrac- } \\
\text { tion } \\
\text { (D sph.) }\end{array}$ & $\begin{array}{l}\text { Corrected } \\
\text { Visual } \\
\text { Acuity }\end{array}$ \\
\hline Normal & $\begin{array}{l}1 \\
2 \\
3 \\
4 \\
5 \\
6 \\
7\end{array}$ & $\begin{array}{l}20 \\
34 \\
25 \\
32 \\
33 \\
35 \\
40\end{array}$ & $\begin{array}{l}\text { M. } \\
\text { F. } \\
\text { M. } \\
\text { M. } \\
\text { F. } \\
\text { M. } \\
\text { M. }\end{array}$ & $\begin{array}{l}-1 \cdot 0 \\
+3 \cdot 0 \\
+2.0 \\
-0.5 \\
+4.0 \\
+2.0 \\
+2.0\end{array}$ & $\begin{array}{l}50 \mathrm{~cm} . \text { C.F. } \\
70 \mathrm{~cm} . \text { C.F. } \\
1 / 60 \\
2 / 60 \\
90 \mathrm{~cm} . \text { C.F. } \\
3 / 60 \\
1 / 60\end{array}$ & $\begin{array}{l}24 \\
25 \\
23 \\
20 \\
21 \\
20 \\
20\end{array}$ & $\begin{array}{l}\text { Opaque } \\
\text { Opaque } \\
\text { Opaque } \\
\text { Opaque } \\
\text { Opaque } \\
\text { Opaque } \\
\text { Opaque }\end{array}$ & Nil & $\begin{array}{l}10 \mathrm{~cm} . \text { C.F. } \\
15 \mathrm{~cm} \text {. C.F. } \\
20 \mathrm{~cm} \text {. C.F. } \\
50 \mathrm{~cm} \text {. C.F. } \\
10 \mathrm{~cm} \text {. C.F. } \\
50 \mathrm{~cm} \text {. C.F. } \\
20 \mathrm{~cm} \text {. C.F. }\end{array}$ \\
\hline Low & $\begin{array}{r}8 \\
9 \\
10\end{array}$ & $\begin{array}{l}25 \\
26 \\
35\end{array}$ & $\begin{array}{l}\text { M. } \\
\text { F. } \\
\text { M. }\end{array}$ & $\begin{array}{l}-11 \cdot 0 \\
-2 \cdot 0 \\
-18.0\end{array}$ & $\begin{array}{l}50 \mathrm{~cm} . \text { C.F. } \\
2 / 60 \\
1 / 60\end{array}$ & $\begin{array}{r}12 \\
8 \\
10\end{array}$ & $\begin{array}{l}\text { Clear } \\
\text { Clear } \\
\text { Clear }\end{array}$ & $\begin{array}{l}-3 \cdot 0 \\
+4 \cdot 0 \\
-10 \cdot 0\end{array}$ & $\begin{array}{l}2 / 60 \\
3 / 60 \\
3 / 60\end{array}$ \\
\hline
\end{tabular}

lamellae remained clear with improved vision. In all the cases in which the ocular tension was normal (i.e. 20 to $25 \mathrm{~mm}$. Hg), a post-keratectomy opacity developed without vascularization.

In Cases 1, 2, and 3 (ocular tension 23 to $25 \mathrm{~mm}$. $\mathrm{Hg}$ ), an accidental traumatic tiny corneal perforation occurred at the edge of the post-operative corneal opacity about 2 months after the operation. This was immediately followed by loss of anterior chamber, soft ocular tension, and disappearance of corneal opacity. Treatment was continued by binocular bandage, rest, and tonics. So long as the ocular tension was soft the thin corneal lamellae remained clear, but as the anterior chamber re-formed and the intra-ocular pressure rose to the normal pre-operative level, the corneal opacity recurred.

In Case 3, after another slight trauma, one year later a corneal perforation involved the upper margin of the corneal opacity. On this occasion the opacity did not disappear as it was by now composed of vascular scar tissue. 
The perforating corneal wound was sutured but leucoma adherens developed with further visual deterioration.

In the first seven cases the post-operative opacities necessitated either tattooing and iridectomy or a partial penetrating keratoplasty.

\section{Discussion}

Theoretically, in the absence of homogeneous donor corneal grafts, a partial lamellar keratectomy appears to be a logical solution to the problem of central avascular superficial corneal opacities. A surgeon lacking experience of this operation may think that the deeper the lamellar keratectomy is done, the better the opacity is removed. In the cases here described the post-keratectomy corneal opacity was not due to infection, vitamin deficiency, vascularization, or allergy. Fluorescein revealed no epithelial defect. Epithelial scraping showed that the opacity lay not only in the epithelium but also in the thin corneal lamellae.

In the living eye the average minimal corneal thickness at the centre is about $0.5 \mathrm{~mm}$., and this increases to $0.74 \mathrm{~mm}$. at an angular distance of $40^{\circ}$ from the centre (Duke-Elder and Wybar, 1961). Bahr (1948) found the average thickness of the central cornea in 125 healthy persons of both sexes to be $0.565 \mathrm{~mm}$. According to Kokott $(1934,1935,1938)$, there is a general tendency for the bundles of corneal substantia propria in the superficial layers to run upwards and downwards vertically, for those in the middle layers to direct themselves towards the insertion of the recti, and for those at the periphery in the deeper layers to form a circular arrangement. Ehlers (1929) demonstrated structural differences between the anterior lamellae and those in the posterior two-thirds of the stroma. The superficial fibre bundles run criss-cross at definite angles, each change of direction involving a change of level. In the deeper stroma, the bundles tend to follow definite planes, which gives this tissue a more truly lamellar structure. The very superficial corneal stroma affords no such plane of cleavage as is found in the deeper layers. A cleavage plane is usually found at a depth of 0.3 to $0.4 \mathrm{~mm}$.

The post-keratectomy corneal opacity did not appear in eyes with a low ocular tension. It appeared in cases with normal tension $(20$ to $25 \mathrm{~mm} . \mathrm{Hg})$ but disappeared if the eye became soft after a corneal perforation. An intra-ocular pressure of 20 to $25 \mathrm{~mm}$. Hg is normal for a corneal thickness of 0.5 to $0.6 \mathrm{~mm}$., but is high for the corneal thickness of 0.1 to $0.2 \mathrm{~mm}$. which remains after partial lamellar keratectomy. Under a tension of 20 to $25 \mathrm{~mm}$. Hg, these thin corneal lamellae become stretched, oedematous, and thus opaque. Adler (1950) pointed out that the corneal cloudiness in acute glaucoma could not be attributed solely to the imbibition of fluid; and concluded that other physical changes took place in the corneal stroma. Even local pilocarpine or general Diamox does not lower the intra-ocular pressure 
sufficiently to counteract the corneal oedema, and the persistence of the oedema promotes scar formation and opacification.

The thin corneal lamellae which remain after keratectomy are liable not only to opacification but also to perforation with the slightest trauma. If the post-keratectomy lamellae remain clear the eye becomes less myopic or more hypermetropic by about 5 to 7 dioptres.

In cases of central superficial corneal opacity, if a donor homogeneous corneal graft is not available, an autogenous lamellar corneal graft taken from the same eye (by the method of Morax, 1912, or of Gradle, 1921) is not followed by renewed corneal opacity as in our keratectomy cases. The sutured graft heals and by the second post-operative week the corneal thickness has reached the normal $0.5 \mathrm{~mm}$., and is thus unaffected by the ocular tension.

\section{Summary}

An intra-ocular pressure of 20 to $25 \mathrm{~mm}$. $\mathrm{Hg}$ (Schiötz), which is normal for a corneal thickness of 0.5 to $0.6 \mathrm{~mm}$., is a relatively high pressure for the corneal thickness of 0.1 to $0.2 \mathrm{~mm}$. which remains after partial lamellar keratectomy. This causes the epithelium and thin corneal lamellae to stretch, and the resultant oedema gives rise to the corneal opacity which usually recurs during the second post-operative week.

Partial lamellar keratectomy should not be done unless the ocular tension is as low as 8 to $12 \mathrm{~mm}$. $\mathrm{Hg}$, and even in such cases not more than $0.3 \mathrm{~mm}$. of the superficial lamellae should be removed. The operation gives the best results in myopic eyes of low ocular tension.

\section{REFERENCES}

AdLer, F. H. (1950). "Physiology of the Eye. Clinical Application", pp. 37-60. Mosby, St. Louis.

BAHR, G. vON (1948). Acta ophthal. (Kbh)., 26, 247.

CASTROviejo, R. (1955). In "Corneal Grafts" ed. B. W. Rycroft, p. 135. Butterworth, London. DUKe-ElDER, S., and WYbar, K. C. (1961). "System of Ophthalmology", vol.2, p. 93. Kimpton, London.

EhLERS, H. (1929). "Nogle experimentelle og anatomiske Undersøgelser over Corneas Kar og Struktur". Busch, Copenhagen.

GradLe, H. S. (1921). Amer. J. Ophthal., 4, 895.

KoKOTт, W. (1934). Klin. Mbl. Augenheilk., 92, 177. (1935). Ibid., 94, 33. (1938). v. Graefes Arch. Ophthal., 138, 424.

Morax, V. (1913). Clin. Ophtal., 19, 108. 